University of Montana

ScholarWorks at University of Montana

Integrative Physiology and Athletic Training

Faculty Publications

Integrative Physiology and Athletic Training

$12-2007$

\title{
Quercetin Ingestion Does Not Alter Cytokine Changes in Athletes Competing in the Western States Endurance Run
}

\author{
David Nieman \\ Appalachian State University \\ Dru Henson \\ Appalachian State University \\ J. Mark Davis \\ University of South Carolina - Columbia \\ Charles Dumke \\ University of Montana - Missoula, charles.dumke@umontana.edu \\ Sarah J. Gross Gowin \\ Appalachian State University \\ See next page for additional authors \\ Follow this and additional works at: https://scholarworks.umt.edu/hhp_pubs \\ Part of the Medicine and Health Sciences Commons \\ Let us know how access to this document benefits you.
}

\section{Recommended Citation}

David C. Nieman, Dru A. Henson, J. Mark Davis, Charles L. Dumke, Sarah J. Gross, D. Paul Jenkins, E. Angela Murphy, Martin D. Carmichael, John C. Quindry, Steven R. McAnulty, Lisa S. McAnulty, Alan C. Utter, and Eugene P. Mayer. Journal of Interferon \& Cytokine Research. December 2007, 27(12): 1003-1012. doi:10.1089/jir.2007.0050.

This Article is brought to you for free and open access by the Integrative Physiology and Athletic Training at ScholarWorks at University of Montana. It has been accepted for inclusion in Integrative Physiology and Athletic Training Faculty Publications by an authorized administrator of ScholarWorks at University of Montana. For more information, please contact scholarworks@mso.umt.edu. 


\section{Authors}

David Nieman, Dru Henson, J. Mark Davis, Charles Dumke, Sarah J. Gross Gowin, D. Paul Jenkins, E. Angela Murphy, Martin D. Carmichael, John C. Quindry, Steven R. McAnulty, Lisa S. McAnulty, Alan C. Utter, and Eugene P. Mayer 


\title{
Quercetin Ingestion Does Not Alter Cytokine Changes in Athletes Competing in the Western States Endurance Run
}

\author{
DAVID C. NIEMAN, ${ }^{1}$ DRU A. HENSON,${ }^{1}$ J. MARK DAVIS,${ }^{2}$ CHARLES L. DUMKE,${ }^{1}$ SARAH J. GROSS,${ }^{1}$ \\ D. PAUL JENKINS, ${ }^{1}$ E. ANGELA MURPHY, ${ }^{2}$ MARTIN D. CARMICHAEL ${ }^{2}$ JOHN C. QUINDRY, ${ }^{1}$ \\ STEVEN R. McANULTY, ${ }^{1}$ LISA S. McANULTY,${ }^{1}$ ALAN C. UTTER, ${ }^{1}$ and EUGENE P. MAYER ${ }^{2}$
}

\begin{abstract}
The purpose of this study was to measure the influence of quercetin on plasma cytokines, leukocyte cytokine mRNA, and related variables in ultramarathoners competing in the 160-km Western States Endurance Run (WSER). Sixty-three runners were randomized to quercetin and placebo groups and under double-blinded methods ingested $1000 \mathrm{mg} /$ day quercetin for 3 weeks before the WSER. Thirty-nine of the 63 subjects $(n=$ 18 for quercetin, $n=\mathbf{2 1}$ for placebo) finished the race and provided blood samples the morning before the race and 15-30 min postrace. Significant prerace to postrace WSER increases were measured for nine proinflammatory and anti-inflammatory plasma cytokines, cortisol (quercetin $=94 \%$, placebo $=96 \%$ ), serum Creactive protein $(\mathrm{CRP})($ mean $\pm \mathrm{SE}$ absolute increase, quercetin $=31.8 \pm 4.2$, placebo $=38.2 \pm 5.0 \mathrm{mg} / \mathrm{L}$ ), and creatine kinase $(\mathrm{CK})$ (quercetin $=21,575 \pm 3,977$, placebo $=19,455 \pm 3,969 \mathrm{U} / \mathrm{L}$ ), with no significant group differences. Interleukin-6 (IL-6) mRNA did not change post-WSER, with a significant decrease measured for leukocyte IL-8 mRNA $(0.21 \pm 0.03$-fold and $0.25 \pm 0.04$-fold change from rest, quercetin and placebo, respectively) and significant increases for IL-1Ra mRNA (1.43 \pm 0.18-fold and 1.40 \pm 0.16-fold change, quercetin and placebo, respectively) and IL-10 mRNA (12.9 \pm 3.9-fold and 17.2 \pm 6.1-fold change, quercetin and placebo, respectively), with no significant differences between groups. In conclusion, quercetin ingestion (1 g/day) by ultramarathon athletes for 3 weeks before a competitive 160 - $\mathrm{km}$ race significantly increased plasma quercetin levels but failed to attenuate muscle damage, inflammation, increases in plasma cytokine and hormone levels, and alterations in leukocyte cytokine mRNA expression.
\end{abstract}

\section{INTRODUCTION}

I NTENSIVE EXERCISE OF LONG DURATION increases blood levels of multiple cytokines, with most of these exerting anti-inflammatory effects. ${ }^{1,2}$ In previous studies of athletes competing in the 160-km Western States Endurance Run (WSER), we have shown that the greatest fold increase is experienced prerace to postrace for interleukin-6 (IL-6) ( $\sim 130$-fold), followed by IL-10 (31-fold), granulocyte colony-stimulating factor (GCSF) (26-fold), IL-8 (9-fold), IL-1 receptor antagonist (IL-1Ra) (7-fold), monocyte chemotactic protein-1 (MCP-1) (3-fold), macrophage inflammatory protein- $1 \beta$ (MIP- $1 \beta$ ) (2-fold), macrophage migration inhibitory factor-1 (MIF-1) (1.5-fold), and tumor necrosis factor- $\alpha$ (TNF- $\alpha)$ (1.3-fold). ${ }^{3-5}$ Underlying mechanisms are being explored, but we have shown that athletes with the greatest degree of muscle damage (as measured by serum creatine kinase $[\mathrm{CK}]$ ) experience the highest postrace plasma levels for most of these cytokines. ${ }^{4,5} \mathrm{IL}-6$, IL-8, IL- $1 \beta$, and TNF- $\alpha$ mRNA content is increased within postexercise muscle biopsy samples, and blood leukocytes may secrete increased amounts of IL-8, IL-10, and IL-1Ra during sustained exercise. $^{6-9}$

Primary signaling mechanisms for cytokine gene expression during exercise are poorly understood, but recent data suggest that nitric oxide (NO) production is a key regulator. ${ }^{9}$ Other potential triggers of cytokine release during extreme exercise in-

${ }^{1}$ Departments of Biology; Health, Leisure, and Exercise Science; Family and Consumer Sciences; and Fischer Hamilton/Nycom Biochemistry Laboratory, Appalachian State University, Boone, North Carolina.

${ }^{2}$ Department of Exercise Science, University of South Carolina, Columbia, South Carolina, and Department of Health, Leisure, and Exercise Science, Appalachian State University, Boone, North Carolina. 
clude leakage of endoxtoxins (lipopolysaccharide [LPS]) from the intestines, elevation in catecholamines and cortisol, high core body temperature, glycogen deficiency and other metabolic demands, and oxidative stress. ${ }^{1-9}$ Carbohydrate feedings during intense and prolonged exercise in the fasted state attenuate increases in plasma stress hormones and IL-6, IL-10, and IL-1Ra but have relatively little effect in athletes consuming prerace meals. ${ }^{6,7}$ Although still debated in regard to benefit vs. risk, a reduction in the inflammatory cytokine response to exercise through nutraceutical or pharmacologic means is a goal being pursued by several research teams worldwide.

Plants contain thousands of phenolic compounds, including more than 5000 flavonoids that exhibit strong antioxidant activity. ${ }^{10-12}$ Flavonols are the most widespread flavonoids in foods, and the most prominent is quercetin. ${ }^{10}$ The richest food sources of quercetin are onions, apples, blueberries, curly kale, tea, and broccoli. ${ }^{11}$ Total flavonol intake (with quercetin representing about $75 \%$ ) varies from 13 to $64 \mathrm{mg} /$ day depending on the study sample and the population studied..$^{10}$ Human subjects can absorb significant amounts of quercetin from food or supplements, and elimination is quite slow, with a reported halflife ranging from 11 to $28 \mathrm{~h} .{ }^{12,13}$ Long-term feeding of quercetin in rats leads to accumulation in several organs, including the lungs, testes, kidney, heart, liver, thymus, and muscle. ${ }^{14}$ Despite earlier concerns, long-term, high-dose quercetin supplementation in rodents and humans has not been linked to any adverse effects. ${ }^{15}$ Epidemiologic studies indicate that higher compared with lower quercetin intake is associated with reduced risk for ischemic heart disease, type 2 diabetes, asthma, and various types of cancer, including lung cancer, colorectal cancer, and prostate cancer. ${ }^{16-19}$

Quercetin is a powerful antioxidant, and in vitro data show that quercetin in aglycone form has an antioxidant potency that is approximately 5 -fold greater than that of vitamin C. ${ }^{20}$ In vitro cell culture studies indicate that quercetin also exerts anti-inflammatory effects and inhibits nuclear factor $-\kappa \mathrm{B}(\mathrm{NF}-\kappa \mathrm{B})$ signaling in a variety of cells, including macrophages and peripheral blood mononuclear cells (PBMCs). ${ }^{20-27}$ Quercetin acts by blocking the protein kinase-mediated $\mathrm{I} \kappa \mathrm{B}$ degradation, thereby preventing NF- $\kappa \mathrm{B}$ activation. ${ }^{28} \mathrm{NF}-\kappa \mathrm{B}$ is a central mediator of immune responses and regulates the expression of genes encoding many cytokines, such as IL- $1 \beta$, TNF- $\alpha$, MCP- 1 , and MIP- $1 \alpha / \beta .^{29} \mathrm{NF}-\kappa \mathrm{B}$ is activated by proinflammatory stimuli, such as TNF- $\alpha$ and LPS, and various stress stimuli, including elevated hormones, physical stress, and oxidative stress. ${ }^{24,29}$ Prostaglandin and NO are also involved in inflammation, and inducible isoforms of nitric oxide synthase (iNOS) and cyclooxygenase (COX-2) are responsible for the production of large amounts of these proinflammatory mediators. ${ }^{28}$ Several in vitro studies indicate that quercetin inhibits $\mathrm{NO}$ production and iNOS expression. ${ }^{23,25,28}$ Thus, inhibition of iNOS by quercetin may be one of the mechanisms responsible for its antiinflammatory effects and may be an important regulatory pathway during exercise, as shown by Steensberg et al. ${ }^{9}$

Given quercetin's antioxidant, anti-inflammatory, and NF$\kappa \mathrm{B}$ and iNOS inhibitory effects, we hypothesized that quercetin compared with placebo supplementation would attenuate leukocyte mRNA expression for cytokines and diminish postrace plasma cytokine levels in endurance athletes competing in the 160-km WSER. We designed a randomized, double-blinded, placebo-controlled study whereby runners registered for the 2006 160-km WSER ingested soft-chew supplements with or without $1000 \mathrm{mg}$ quercetin for 3 weeks prior to the race event. Blood samples were collected 1 day prerace and immediately after completion of the race and analyzed for nine cytokines, leukocyte cytokine mRNA expression, cortisol, C-reactive protein (CRP), CK, and various diagnostic chemistries.

\section{MATERIALS AND METHODS}

\section{Subjects and race description}

Sixty-three experienced male and female ultramarathoners from the 2006 160-km WSER were recruited and randomized to quercetin and placebo groups. Thirty-nine of the 63 subjects ( $n=18$ for quercetin with 14 males and 4 females, $n=21$ for placebo with 18 males and 3 females) finished the race and provided blood samples prerace and postrace. Prior to testing, informed consent was obtained from each subject, and the experimental procedures were approved by the institutional review board of Appalachian State University. To enter the study, subjects must have qualified for the 2006 160-km WSER (qualification criteria: completed a $160-\mathrm{km}$ trail race or three $80-\mathrm{km}$ races within the cutoff times or raced $80-\mathrm{km}$ in under $11 \mathrm{~h}$ or $100-\mathrm{km}$ in under $14 \mathrm{~h}$ ).

The $160-\mathrm{km}$ WSER is a point-to-point trail run in the Sierra Nevada Mountains of northern California and is regarded as one of the most arduous organized running events in the United States. The race starts at Squaw Valley, California (1890 m altitude), and finishes at Auburn, California (366 m). The trail race course ascends $777 \mathrm{~m}$ to Emigrant Pass (2668 m, the highest point) within the first $7 \mathrm{~km}$ and then passes through remote and rugged territory to Auburn. The total altitude gain and loss during the race is $5500 \mathrm{~m}$ and $6700 \mathrm{~m}$, respectively. The race starts at 5:00 AM, and runners must reach the finish line within $30 \mathrm{~h}$ to be eligible for an award.

\section{Research design}

Following recruitment and randomization, subjects ingested soft chews with or without $1000 \mathrm{mg} /$ day quercetin using double-blinded procedures for 3 weeks before and the morning of the WSER. This quercetin dosage was based on unpublished animal data (J. Mark Davis, personal communication). Subjects in the quercetin group ingested four soft, individually wrapped chews each day (two prior to breakfast and two prior to dinner) that contained $250 \mathrm{mg}$ quercetin, $250 \mathrm{mg}$ vitamin $\mathrm{C}, 20$ $\mathrm{mg}$ niacin, and $20 \mathrm{kcal}$ sugars in a carnauba wax and soy lecithin base colored with FD\&C yellow 6 (Nutravail Technologies Inc., Chantilly, VA, and Quercegen Pharma, Newton, MA). Placebo supplements were prepared exactly the same way minus the quercetin, vitamin C, and niacin. Data from Quercegen Pharma indicate that the bioavailability of quercetin is enhanced with vitamin $\mathrm{C}$ and niacin, and thus this study tested whether or not soft chews with or without the combination of quercetin, vitamin $\mathrm{C}$, and niacin had an influence on the outcome measures. On race day, subjects ingested all four chews prior to the 5:00 AM start time. During the prerace supplementation period, subjects were instructed to ingest their normal intake of food, beverages, and supplements while avoiding any other supplements 
containing quercetin, with verification by a dietitian following the race. A 3-day food record was obtained during the 3-week prerace supplementation period and analyzed using the computerized nutrition software program, Food Processor (ESHA Research, Salem, OR).

Subjects provided blood samples during registration in Squaw Valley, held the morning before the race, and 15-30 min postrace in Auburn. Plasma aliquots were frozen immediately, transported on dry ice, and then stored at $-80^{\circ} \mathrm{C}$ until analysis. During race registration, body mass was measured, and subjects filled in a questionnaire on basic demographics and training history. On race day, body mass was measured at the $90-\mathrm{km}$ aid station (Michigan Bluff, $1220 \mathrm{~m}$ ) and within 5-15 min postrace at Auburn. Subjects completed a postrace questionnaire indicating adherence to the research design. Subjects consumed food and beverages ad libitum during the race.

\section{Plasma quercetin}

Total plasma quercetin (quercetin and its primary conjugates) was measured following solid-phase extraction via reversephase HPLC with UV detection as described by Quercegen Pharma. This procedure is similar to that previously published by Ishii et al. ${ }^{30}$ Quercetin conjugates were hydrolyzed by incubating 250-500 $\mu \mathrm{L}$ plasma aliquots with $10 \mu \mathrm{L} 10 \%$ DLdithiothreitol (DTT) solution, $50 \mu \mathrm{L} 0.58 \mathrm{M}$ acetic acid, $50 \mu \mathrm{L}$ of a mixture of $\beta$-glucuronidase and arylsulfatase, and crude extract from Helix pomatia (Roche Diagnostics $\mathrm{GmbH}$, Mannheim, Germany) for $40 \mathrm{~min}$ at $37^{\circ} \mathrm{C}$. After incubation, 500 $\mu \mathrm{L}$ of $0.01 \mathrm{M}$ oxalic acid was added, and each sample was vortexed and centrifuged for $5 \mathrm{~min}$ at 10,000 rpm. Supernatants (1 $\mathrm{mL}$ ) were then applied to solid-phase extraction cartridges (Oasis HLB 1cc, $30 \mathrm{mg}$, SPE cartridge) (Waters Corp., Milford, $\mathrm{MA})$ that were preconditioned with $1 \mathrm{~mL}$ methanol $(\mathrm{MeOH})$, $0.5 \mathrm{~mL} 0.01 \mathrm{M}$ oxalic acid, and $1 \mathrm{~mL} \mathrm{dH}_{2} \mathrm{O}$ and drawn through at a rate of $0.5 \mathrm{~mL} / \mathrm{min}$ using a vacuum manifold (Waters Corp). Cartridges were washed with $0.5 \mathrm{~mL} \mathrm{MeOH} \times 2$. Eluant was collected into $1.5-\mathrm{mL}$ microcentrifuge tubes. DTT (10\% solution, $10 \mu \mathrm{L}$ ) was added to the combined eluant, and the samples were vortexed for $1 \mathrm{~min}$ and placed in a vacuum concentrator (Savant Speed Vac SC 110, Savant Instruments Inc., Farmindale, NY) until $\mathrm{MeOH}$ was completely evaporated. The residue was reconstituted with $150 \mu \mathrm{L} \mathrm{MeOH} / \mathrm{dH}_{2} \mathrm{O}$ (1:1). Injections $(50 \mu \mathrm{L})$ were used for HPLC analysis.

Chromatographic analysis was performed using a Waters Breeze system (Waters Corp.) consisting of a Waters $1525 \mathrm{Bi}$ nary HPLC pump, 2487 UV detector, and Symmetry C18 $5 \mu \mathrm{m}$
4.6 $\times 150-\mathrm{mm}$ column. The analysis data were acquired and processed using Breeze software (v3.02). A mixture of acetonitrile with $0.1 \%$ formic acid (A) and $\mathrm{dH}_{2} \mathrm{O}$ with $0.1 \%$ formic acid (B) was used as the mobile phase. The gradient elution was programmed as follows: $0-1.5 \mathrm{~min}, 10 / 90 \% \mathrm{~A} / \mathrm{B} ; 1.5-9.5$ $\min , 40 / 60 \% \mathrm{~A} / \mathrm{B} ; 9.5-11.5 \mathrm{~min}, 90 / 10 \% \mathrm{~A} / \mathrm{B} ; 11.5-15 \mathrm{~min}$, $10 / 90 \% \mathrm{~A} / \mathrm{B}$. The column temperature was maintained at $30^{\circ} \mathrm{C}$. The flow rate was $1.0 \mathrm{~mL} / \mathrm{min}$. Quantification of the quercetin peak was based on the standard addition method using both plasma and $\mathrm{MeOH}$, with similar results. Standards and samples were treated in an identical manner.

\section{Cytokine measurements}

Total plasma concentrations of IL-1Ra, IL-6, IL-8, IL-10, G-CSF, MCP-1, MIP- $1 \beta$, TNF- $\alpha$, and MIF- 1 were determined using quantitative sandwich ELISA kits provided by R\&D Systems, Inc. (Minneapolis, MN). All samples and provided standards were analyzed in duplicate. High sensitivity kits were used to analyze TNF- $\alpha$ and prerace samples of IL-6, IL-10, and G-CSF. The minimum detectable concentration of IL-1Ra was $<22 \mathrm{pg} \cdot \mathrm{mL}^{-1}$, IL-6 $<0.70 \mathrm{pg} \cdot \mathrm{mL}^{-1}$, IL-6 (high sensitivity) $<0.039 \mathrm{pg} \cdot \mathrm{mL}^{-1}$, IL-8 $<3.5 \mathrm{pg} \cdot \mathrm{mL}^{-1}$, IL-10 $<3.9 \mathrm{pg} \cdot$ $\mathrm{mL}^{-1}$, IL-10 (high sensitivity) $<0.50 \mathrm{pg} \cdot \mathrm{mL}^{-1}$, G-CSF $<20.0 \mathrm{pg} \cdot \mathrm{mL}^{-1}, \mathrm{G}-\mathrm{CSF}$ (high sensitivity) $<0.80 \mathrm{pg} \cdot \mathrm{mL}^{-1}$, MCP-1 $<5.0 \mathrm{pg} \cdot \mathrm{mL}^{-1}$, MIP- $1 \beta<11.0 \mathrm{pg} \cdot \mathrm{mL}^{-1}$, TNF- $\alpha$ $<0.106 \mathrm{pg} \cdot \mathrm{mL}^{-1}$, and MIF-1 $<0.017 \mathrm{ng} \cdot \mathrm{mL}^{-1}$. To improve sensitivity in the detection of IL-8, we employed SOFTmax analysis software (Molecular Devices, Sunnyvale, CA). Preexercise and postexercise samples for the cytokines were analyzed on the same assay plate to decrease interkit assay variability.

\section{Leukocyte mRNA extraction and cDNA synthesis}

The QIAampRNA Blood Mini Kit Protocol (Qiagen, Valencia CA) was used to extract mRNA. From each subject, 3$\mathrm{mL}$ aliquots of whole blood collected in EDTA were purified for RNA. Briefly, erythrocytes were selectively lysed, and leukocytes were recovered by centrifugation. Samples were briefly centrifuged through a QIAshredder spin column, ethanol was added to adjust binding conditions, and the sample was applied to a QIAamp spin column. RNA was bound to the silica gel membrane during a brief centrifugation step. Contaminants were washed away, and total RNA was eluted in $30 \mu \mathrm{L}$ RNase-free water.

The extracted RNA (7.5 $\mu \mathrm{L}$ of sample) was dissolved in diethylpyrocarbonate-treated water and quantified spectrophoto-

Table 1. Subject Characteristics (Mean \pm SE)

\begin{tabular}{lccr}
\hline Variable & Quercetin $(\mathrm{n}=18)$ & Placebo $(\mathrm{n}=21)$ & $\mathrm{p}$ value \\
\hline Age, years & $44.2 \pm 2.0$ & $46.0 \pm 2.3$ & 0.575 \\
Running experience, years & $13.0 \pm 2.3$ & $13.3 \pm 1.7$ & 0.780 \\
Ultramarathons raced & $39.6 \pm 10.6$ & $37.9 \pm 6.0$ & 0.988 \\
Training distance, $\mathrm{km} \cdot \mathrm{wk}^{-1}$ & $83.4 \pm 5.0$ & $75.8 \pm 7.1$ & 0.398 \\
Race time, h & $26.4 \pm 0.7$ & $27.5 \pm 0.6$ & 0.237 \\
Body mass, prerace, $\mathrm{kg}$ & $68.9 \pm 2.7$ & $73.9 \pm 2.7$ & 0.168 \\
Body mass, midrace, $\mathrm{kg}$ & $68.9 \pm 2.3$ & $73.5 \pm 2.7$ & 0.169 \\
Body mass, postrace, $\mathrm{kg}$ & $68.0 \pm 2.3$ & $73.0 \pm 2.7$ & 0.140 \\
\hline
\end{tabular}




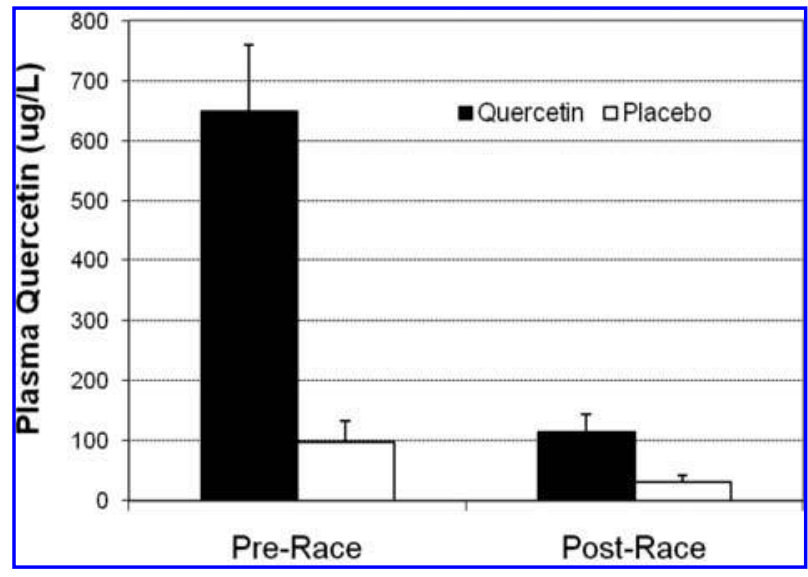

FIG. 1. Plasma quercetin in runners before and after a 160$\mathrm{km}$ race in quercetin $(n=18)$ and placebo $(n=20)$ groups. Time effect, $p<0.001 ;$ quercetin/placebo group $\times$ time effect, $p<0.001$.

metrically at 260-nm wavelength. RNA was reverse transcribed into cDNA in a $50 \mu \mathrm{L}$ reaction volume containing $19.25 \mu \mathrm{L}$ RNA in RNase-free water, $5 \mu \mathrm{L} 10 \times$ RT buffer, $11 \mu \mathrm{L} 25 \mathrm{mM}$ $\mathrm{MgCl}_{2}, 10 \mu \mathrm{L}$ deoxyNTPs mixture, $2.5 \mu \mathrm{L}$ random hexamers, $1 \mu \mathrm{L}$ RNase inhibitor, and $1.25 \mu \mathrm{L}$ multiscribe reverse transcriptase $(50 \mathrm{U} / \mu \mathrm{L})$. Reverse transcription was performed at $25^{\circ} \mathrm{C}$ for $10 \mathrm{~min}, 37^{\circ} \mathrm{C}$ for $60 \mathrm{mins}$, and $95^{\circ} \mathrm{C}$ for $5 \mathrm{~min}$, followed by quick chilling on ice, and stored at $-20^{\circ} \mathrm{C}$ until subsequent amplification.

\section{Quantitative real-time PCR analysis}

Quantitative RT-PCR analysis was done as per manufacturer's instructions (Applied Biosystems, Foster City, CA) us- ing TaqMan Gene Expression Assays. DNA amplification was carried out in 12.5 Taqman Universal PCR Master Mix (AmpliTaq Gold DNA Polymerase, Passive Reference 1, Buffer, dNTPs, AmpErase UNG), $1 \mu \mathrm{L}$ cDNA, $9 \mu \mathrm{L}$ RNase-free water, and $1.25 \mu \mathrm{L} 18 \mathrm{~S}$ primer (VIC) and $1.25 \mu \mathrm{l}$ primer (FAM) (for endogenous reference and target cytokine) in a final volume of $25 \mu \mathrm{L} /$ well. Human control RNA (calibrator RNA) was also used and served as a calibrator for each plate. Samples were loaded in a MicroAmp 96-well reaction plate. Plates were run using ABI Sequence Detection System (Applied Biosystems). After $2 \mathrm{~min}$ at $50^{\circ} \mathrm{C}$ and $10 \mathrm{~min}$ at $95^{\circ} \mathrm{C}$, plates were coamplified by 50 repeated cycles, of which one cycle consisted of a 15-sec denaturing step at $95^{\circ} \mathrm{C}$ and 1-min annealing/extending step at $60^{\circ} \mathrm{C}$. Data was analyzed by ABI software using the cycle threshold (CT), which is the value calculated and based on the time (measured by PCR cycle number) at which the reporter fluorescent emission increases beyond a threshold level (based on the background fluorescence of the system), ${ }^{31}$ and it reflects the cycle number at which the cDNA amplification is first detected. We have previously reported detailed methodology concerning the dual amplification technique. ${ }^{6,7}$ Samples were run in duplicate, and the intraassay and interassay coefficients of variation (CVs) were determined to be $1.69 \%$ and $1.65 \%$ for the $\Delta \mathrm{CTs}$, respectively.

\section{Calculations for relative quantification}

Quantification of cytokine gene expression for IL-8, IL-10, IL-1Ra, and IL-6 was calculated using the $\Delta \Delta \mathrm{CT}$ method as described by Livak and Schmittgen. ${ }^{32}$ This method uses a single sample, the calibrator sample, for comparison of every unknown sample's gene expression. This method of analysis and quantification has been shown to give similar results to the standard curve method. ${ }^{31}$ Briefly, $\Delta \mathrm{CT}(\mathrm{CT}(\mathrm{FAM})-\mathrm{CT}(\mathrm{VIC}))$ was calculated for each sample and calibrator. $\Delta \Delta \mathrm{CT}(\Delta \mathrm{CT}$ (cal-

Table 2. Prerace and Postrace (160 km) Serum Glucose, Cortisol, C-Reactive Protein, Creatine Kinase, and Diagnostic Chemistries in Quercetin $(n=18)$ and Placebo $(n=21)$ Groups (Mean \pm SE)

\begin{tabular}{|c|c|c|c|}
\hline Variable & Prerace & Postrace & $\begin{array}{l}\text { Time; interaction } \\
\text { effects, } \mathrm{p} \text { value }\end{array}$ \\
\hline \multicolumn{4}{|c|}{ Glucose, $\mathrm{mmol} \cdot \mathrm{L}^{-1}$} \\
\hline Quercetin & $5.17 \pm 0.17$ & $6.49 \pm 0.33$ & \multirow[t]{2}{*}{$<0.001 ; 0.355$} \\
\hline Placebo & $5.54 \pm 0.20$ & $6.38 \pm 0.28$ & \\
\hline \multicolumn{4}{|c|}{ Cortisol, $\mathrm{nmol} \cdot \mathrm{L}^{-1}$} \\
\hline Quercetin & $434 \pm 34$ & $835 \pm 80$ & \multirow[t]{2}{*}{$<0.001 ; 0.956$} \\
\hline Placebo & $412 \pm 29$ & $806 \pm 97$ & \\
\hline \multicolumn{4}{|c|}{ C-reactive protein, $\mathrm{mg} \cdot \mathrm{L}^{-1}$} \\
\hline Quercetin & $0.4 \pm 0.1$ & $32.2 \pm 4.3$ & \multirow[t]{2}{*}{$<0.001 ; 0.346$} \\
\hline Placebo & $0.8 \pm 0.2$ & $39.0 \pm 5.1$ & \\
\hline \multicolumn{4}{|c|}{ Creatine kinase, $\mathrm{U} \cdot \mathrm{L}^{-1}$} \\
\hline Quercetin & $159 \pm 25$ & $21733 \pm 3980$ & \multirow[t]{2}{*}{$<0.001 ; 0.710$} \\
\hline Placebo & $171 \pm 27$ & $19626 \pm 3981$ & \\
\hline \multicolumn{4}{|c|}{ Alanine aminotransferase, $\mathrm{U} \cdot \mathrm{L}^{-1}$} \\
\hline Quercetin & $26.1 \pm 1.1$ & $132 \pm 20$ & \multirow[t]{2}{*}{$<0.001 ; 0.598$} \\
\hline Placebo & $26.1 \pm 1.9$ & $118 \pm 18$ & \\
\hline \multicolumn{4}{|c|}{ Aspartate aminotransferase, $\mathrm{U} \cdot \mathrm{L}^{-1}$} \\
\hline Quercetin & $28.9 \pm 1.3$ & $528 \pm 75$ & \multirow[t]{2}{*}{$<0.001 ; 0.937$} \\
\hline Placebo & $29.6 \pm 1.6$ & $519 \pm 95$ & \\
\hline \multicolumn{4}{|c|}{ Blood urea nitrogen, $\mathrm{mmol} \cdot \mathrm{L}^{-1}$} \\
\hline Quercetin & $4.7 \pm 0.3$ & $11.0 \pm 1.0$ & \multirow{2}{*}{$<0.001 ; 0.888$} \\
\hline Placebo & $4.8 \pm 0.4$ & $10.9 \pm 1.0$ & \\
\hline
\end{tabular}


Table 3. Prerace and Postrace (160 Km) Plasma Cytokine Levels in Quercetin $(n=18)$ and Placebo $(n=21)$ Groups (Mean \pm SE)

\begin{tabular}{|c|c|c|c|}
\hline Variable & Prerace & Postrace & $\begin{array}{c}\text { Time; interaction } \\
\text { effects, } \mathrm{p} \text { value }\end{array}$ \\
\hline \multicolumn{4}{|c|}{$\mathrm{IL}-6, \mathrm{pg} \cdot \mathrm{ml}^{-1}$} \\
\hline Quercetin & $0.9 \pm 0.1$ & $90.4 \pm 21.0$ & \multirow{2}{*}{$<0.001 ; 0.340$} \\
\hline Placebo & $1.2 \pm 0.4$ & $66.5 \pm 14.6$ & \\
\hline \multicolumn{4}{|c|}{$\mathrm{IL}-10, \mathrm{pg} \cdot \mathrm{ml}^{-1}$} \\
\hline Quercetin & $9.5 \pm 0.5$ & $132.1 \pm 28.6$ & \multirow[t]{2}{*}{$<0.001 ; 0.228$} \\
\hline Placebo & $9.2 \pm 0.3$ & $89.3 \pm 20.8$ & \\
\hline \multicolumn{4}{|c|}{$\mathrm{G}-\mathrm{CSF}, \mathrm{pg} \cdot \mathrm{ml}^{-1}$} \\
\hline Quercetin & $34.6 \pm 3.1$ & $264.2 \pm 68.8$ & \multirow[t]{2}{*}{$0.001 ; 0.908$} \\
\hline Placebo & $30.8 \pm 2.8$ & $246.7 \pm 90.3$ & \\
\hline \multicolumn{4}{|c|}{$\mathrm{IL}-1 \mathrm{Ra}, \mathrm{pg} \cdot \mathrm{ml}^{-1}$} \\
\hline Quercetin & $137 \pm 6$ & $1037 \pm 228$ & \multirow[t]{2}{*}{$<0.001 ; 0.769$} \\
\hline Placebo & $123 \pm 9$ & $919 \pm 261$ & \\
\hline \multicolumn{4}{|c|}{$\mathrm{IL}-8, \mathrm{pg} \cdot \mathrm{ml}^{-1}$} \\
\hline Quercetin & $4.5 \pm 0.2$ & $25.3 \pm 3.7$ & \multirow[t]{2}{*}{$<0.001 ; 0.415$} \\
\hline Placebo & $5.1 \pm 0.3$ & $21.6 \pm 3.7$ & \\
\hline \multicolumn{4}{|c|}{$\mathrm{MCP}-1, \mathrm{pg} \cdot \mathrm{ml}^{-1}$} \\
\hline Quercetin & $129 \pm 8$ & $529 \pm 52$ & \multirow[t]{2}{*}{$<0.001 ; 0.423$} \\
\hline Placebo & $122 \pm 6$ & $473 \pm 36$ & \\
\hline \multicolumn{4}{|c|}{ MIP- $1 \beta, \mathrm{pg} \cdot \mathrm{ml}^{-1}$} \\
\hline Quercetin & $35.4 \pm 2.8$ & $73.1 \pm 10.4$ & \multirow[t]{2}{*}{$<0.001 ; 0.300$} \\
\hline Placebo & $33.5 \pm 2.8$ & $99.0 \pm 22.6$ & \\
\hline \multicolumn{4}{|c|}{$\mathrm{TNF}-\alpha, \mathrm{pg} \cdot \mathrm{ml}^{-1}$} \\
\hline Quercetin & $0.93 \pm 0.11$ & $1.62 \pm 0.12$ & \multirow[t]{2}{*}{$<0.001 ; 0.287$} \\
\hline Placebo & $1.15 \pm 0.11$ & $2.34 \pm 0.42$ & \\
\hline \multicolumn{4}{|c|}{ MIF-1, ng $\cdot \mathrm{ml}^{-1}$} \\
\hline Quercetin & $5.4 \pm 0.5$ & $12.0 \pm 1.5$ & \multirow[t]{2}{*}{$<0.001 ; 0.667$} \\
\hline Placebo & $4.7 \pm 0.3$ & $12.3 \pm 1.8$ & \\
\hline
\end{tabular}

ibrator) $-\Delta \mathrm{CT}$ (sample)) was then calculated for each sample, and relative quantification was calculated as $2 \Delta \Delta \mathrm{CT}$. Initial exclusion criteria consisted of FAM CT $\geq 40$ and VIC CT $\geq 23$.

Hemoglobin, hematocrit, diagnostic chemistries, CRP, CK cortisol

Complete blood counts for hemoglobin and hematocrit were measured using a Coulter STKS instrument (Coulter Electronics, Inc., Hialeah, FL). Plasma volume changes were estimated using the method of Dill and Costill. ${ }^{33}$ The comprehensive diagnostic chemistry panel, CRP, and CK were measured in a clinical laboratory using an LX-20 clinical analyzer (Beckman, Brea, CA).

Plasma concentrations of cortisol were determined using the competitive solid-phase 125I radioimmunoassay (RIA) technique (Diagnostic Products Corporation, Los Angeles, CA) with cortisol-specific antibody $(\mathrm{Ab})$ coated tubes (Coat-A-Count tubes). Intraassay (CVintra) and interassay (CVinter) CVs were $4.5 \%$ and $5 \%$, respectively. Assay sensitivity was $5.5 \mathrm{nmol} / \mathrm{L}$ $(0.2 \mu \mathrm{g} / \mathrm{dL})$.

\section{Delayed onset of muscle soreness (DOMS)}

Subjects recorded muscle soreness after the race and during the week following the race using a 10-point Likert scale. ${ }^{34}$ Runners were asked to supply a number that best described any general feeling of painful, sore, aching leg muscles using this scale: 1 (no soreness), 2.5 (dull, vague ache), 4 (slight sore- ness), 5.5 (more than slight soreness), 7 (sore), 8.5 (very sore), and 10 (unbearably sore).

\section{Statistical analysis}

Data are expressed as mean $\pm \mathrm{SE}$, and were analyzed using a 2 (groups) $\times 2$ (time points) repeated measures ANOVA.



FIG. 2. IL-8 mRNA expression in blood leukocytes from runners before and after a $160-\mathrm{km}$ race in quercetin $(n=18)$ and placebo $(n=20)$ groups. Values are expressed as a fold change from rest, with rest equal to 1 . Time effect, $p<0.001$; quercetin/placebo group $\times$ time effect, $p=0.437$. 


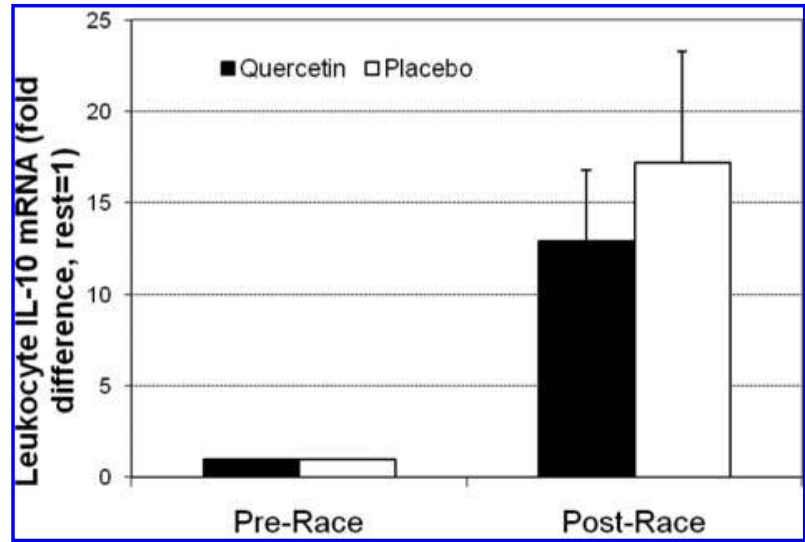

FIG. 3. IL-10 mRNA expression in blood leukocytes from runners before and after a $160-\mathrm{km}$ race in quercetin $(n=18)$ and placebo $(n=20)$ groups. Values are expressed as a fold change from rest, with rest equal to 1 . Time effect, $p=0.001$; quercetin/placebo group $\times$ time effect, $p=0.568$.

When the interaction effect was significant $(p \leq 0.05)$, prerace to postrace changes were calculated and compared between quercetin and placebo groups using Student's $t$-tests, with significance set at $p \leq 0.05$. DOMS data were analyzed using a $2 \times 8$ repeated measures ANOVA. When Box's M suggested that the assumptions necessary for the univariate approach were not tenable, the multivariate approach to repeated measures ANOVA was used (Pillais trace).

\section{RESULTS}

Thirty-nine of 63 subjects ( $n=18$ for quercetin, $n=21$ for placebo) completed the $160-\mathrm{km}$ race event and adhered to all aspects of the study design. A poststudy questionnaire revealed a successful implementation of the double-blinded supplementation (of quercetin subjects, 22\% indicated they were on quercetin, $17 \%$ on placebo, and $61 \%$ were not sure, compared with $38 \%, 29 \%$, and $33 \%$, respectively, of placebo subjects).

Air temperature was $22^{\circ} \mathrm{C}$ at the start of the race at 5:00 AM (Squaw Valley, CA), $38^{\circ} \mathrm{C}$ by 2:00 PM (Michigan Bluff), $27^{\circ} \mathrm{C}$ by 12:00 AM (race finish, Auburn, CA), and $31^{\circ} \mathrm{C}$ by $11: 00 \mathrm{AM}$. The humidity ranged from $25 \%$ to $58 \%$ during the last half of the race. There were no significant differences in subject characteristics between the quercetin and placebo groups (Table 1). Male $(n=32)$ and female $(n=7)$ runners did not differ significantly in race time $(27.0 \pm 0.5 \mathrm{~h}$ vs. $27.0 \pm 1.39 \mathrm{~h}$, respectively, $p=0.992$ ) or change in any of the other variables measured in this study except for those related to body mass and composition. Thus, male and female runner data were combined for this analysis.

Plasma volume did not change appreciably and did not differ significantly between groups $(-0.3 \pm 0.5 \%$ and $-0.3 \pm$ $0.4 \%$, respectively, $p=0.928$ ), and body mass was maintained near prerace levels for both groups (Table 1). Three-day food records prior to the race event indicated no significant differences in macronutrient intakes between groups, with a mean energy intake for all subjects combined of $11.0 \pm 0.8 \mathrm{MJ}$. day $^{-1}\left(2620 \pm 184 \mathrm{kcal} \cdot\right.$ day $\left.^{-1}\right)$ and percent of energy intakes of $51.1 \pm 2.3 \%$ carbohydrate, $31.5 \pm 1.8 \%$ fat, and $18.0 \pm$ $1.2 \%$ protein.

After 3 weeks of supplementation, plasma quercetin levels were 6.6-fold higher in the quercetin compared with the placebo group and 3.1-fold higher postrace (interaction effect, $p<$ 0.001) (Fig. 1). Prerace to postrace increases in serum glucose, cortisol, CRP, CK, alanine and asparate aminotransferase, and blood urea nitrogen did not differ significantly between quercetin and placebo groups (Table 2). Prerace to postrace increases in nine cytokines listed in Table 3 did not differ significantly between quercetin and placebo groups.

Figures 2, 3, 4, and 5 summarize the leukocyte cytokine mRNA data. Leukocyte IL-8 mRNA decreased significantly postrace, with no differences between quercetin and placebo groups (Fig. 2). Leukocyte IL-10 mRNA (Fig. 3) and IL-1Ra mRNA (Fig. 4) increased significantly postrace, with no group differences. Leukocyte IL-6 mRNA did not change postrace, with no group differences (Fig. 5).

Quercetin and placebo groups did not differ in ratings for DOMS on race day or the week after the race (interaction effect, $p=0.986$ ) (Fig. 6).

\section{DISCUSSION}

High-dose quercetin ingestion (1 g/day) by ultramarathon athletes for 3 weeks significantly increased plasma quercetin levels but failed to attenuate muscle damage, DOMS, inflammation, substantial increases in plasma cytokine and hormone levels, and alterations in leukocyte cytokine mRNA expression following the 160-km WSER.

The athletes consuming quercetin for 3 weeks achieved plasma quercetin levels that were 6.6-fold greater than those of athletes randomized to placebo ingestion. On the day of the race, athletes in the quercetin group consumed $1 \mathrm{~g}$ between 4 and 5 AM but did not consume additional quercetin supplements during the race. Plasma quercetin levels in the quercetin group fell to $115 \mu \mathrm{g} / \mathrm{L}$ after the $160-\mathrm{km}$ race, a concentration similar to prerace levels in the placebo group. The half-life of quercetin

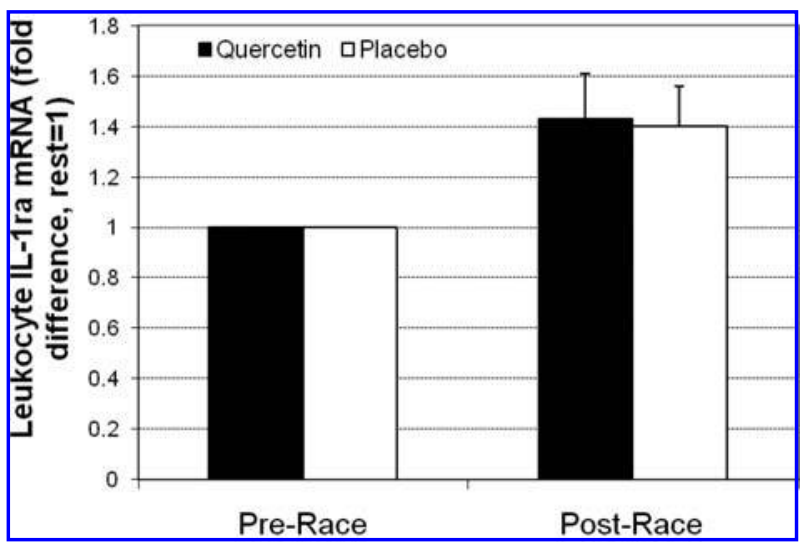

FIG. 4. IL-1Ra mRNA expression in blood leukocytes from runners before and after a $160-\mathrm{km}$ race in quercetin $(n=18)$ and placebo $(n=20)$ groups. Values are expressed as a fold change from rest, with rest equal to 1 . Time effect, $p=0.001$; quercetin/placebo group $\times$ time effect, $p=0.888$. 


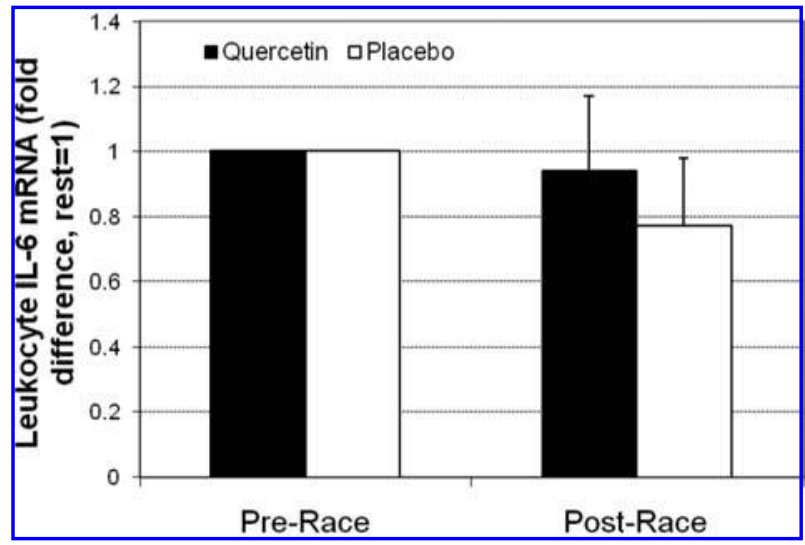

FIG. 5. IL-6 mRNA expression in blood leukocytes from runners before and after a $160-\mathrm{km}$ race in quercetin $(n=18)$ and placebo $(n=20)$ groups. Values are expressed as a fold change from rest, with rest equal to 1 . Time effect, $p=0.351$; quercetin/placebo group $\times$ time effect, $p=0.577$.

has been reported to be 11-28 h, and we hypothesized that plasma quercetin levels would remain high during the race after 3 weeks of supplementation and a full $1 \mathrm{~g}$ quercetin dose just prior to the start of the race. This is the first study of human athletes using high-dose quercetin supplements prior to ultramarathon competition, and we learned that the plasma quercetin level fell substantially more than expected. Ingestion of quercetin supplements throughout the race would have maintained plasma quercetin at a higher level, with perhaps different outcomes.

The results of this study, however, are consistent with those of most other investigations that have failed to show that ingestion of antioxidants, such as vitamins $\mathrm{E}$ and $\mathrm{C}$, has meaningful effects on exercise-induced inflammation, muscle damage, increases in plasma cytokines, and immune perturbations. ${ }^{2,35,36}$ In contrast to our previous findings showing the importance of muscle damage, we have been unable to demonstrate that oxidative stress is strongly associated with inflammation or cytokine changes in athletes competing in ultramarathons. ${ }^{3-5}$ We had hypothesized that a stronger antioxidant, such as quercetin, would prove more useful than vitamin $\mathrm{C}$ or vitamin $\mathrm{E}$ as a nutritional countermeasure to exercise-induced cytokine changes for endurance athletes, but our findings were not supportive. 22

In vitro/cell culture data indicate that quercetin in aglycone form exerts impressive antioxidant and anti-inflammatory effects and inhibits proinflammatory cytokine production and gene expression through modulation of NF- $\kappa$ B. ${ }^{20-23,28}$ Available data demonstrate, however, that quercetin undergoes considerable chemical modification during digestion and absorption and is metabolized to methylated, glucurono-sulfated derivates. ${ }^{12,13,22}$ The quercetin conjugates may have altered bi-

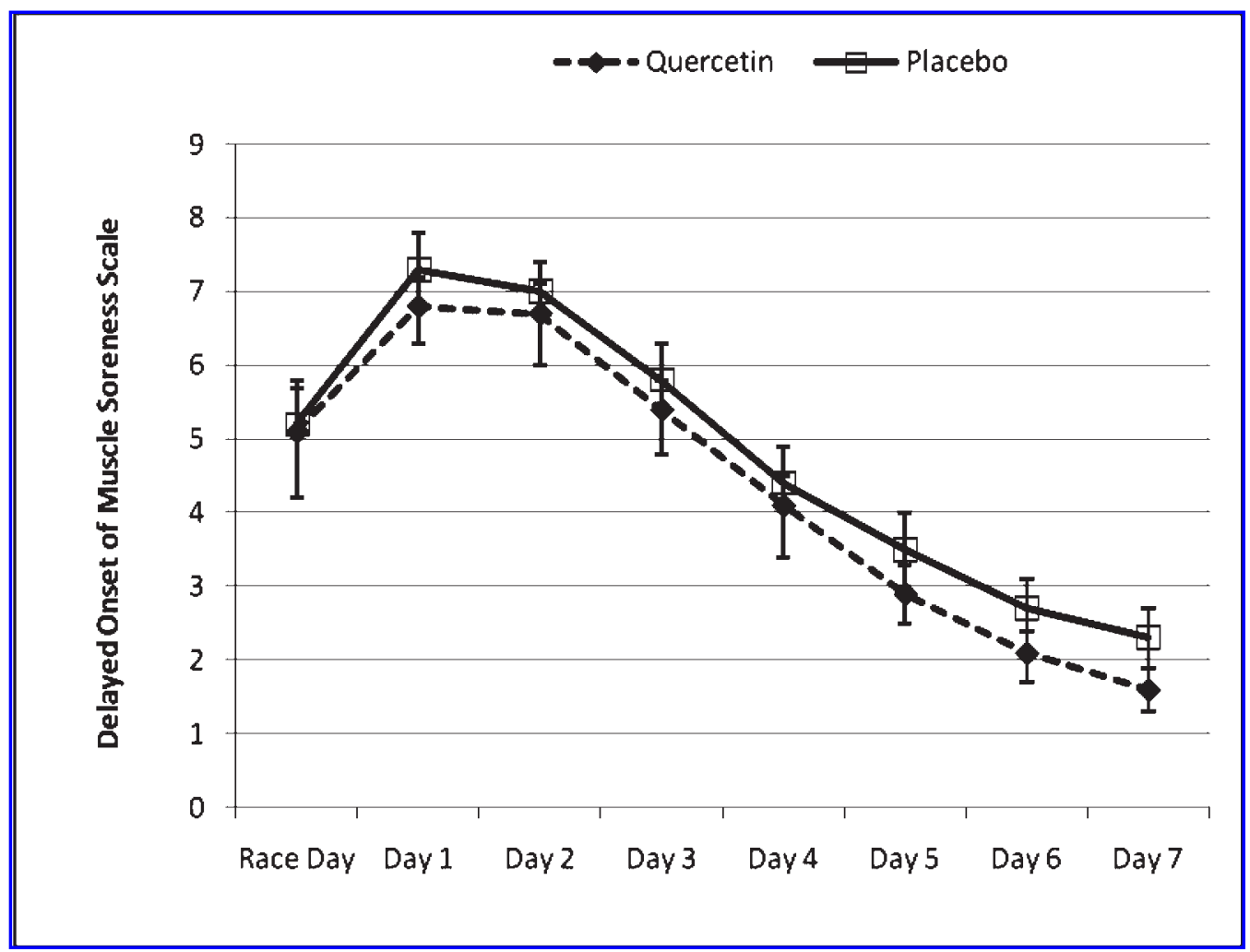

FIG. 6. Delayed onset of muscle soreness (DOMS) in runners on race day and the week following a 160-km race in quercetin $(n=18)$ and placebo $(n=21)$ groups. Time effect, $p<0.001$; quercetin/placebo group $\times$ time effect, $p=0.986$. DOMS scale: 1 (no soreness), 2.5 (dull, vague ache), 4 (slight soreness), 5.5 (more than slight soreness), 7 (sore), 8.5 (very sore), and 10 (unbearably sore). 
ologic properties and potencies when compared with in vitro quercetin aglycone experiments, but few human data are available. ${ }^{22,27}$ Chen et al. ${ }^{22}$ showed that in contrast to quercetin in aglycone form, quercetin- 3 '-sulfate had no antioxidant or inhibitory effects on LPS-induced and interferon- $\gamma$ (IFN- $\gamma$ )-induced iNOS gene expression in mouse BV-2 microglia cell cultures. Another factor to consider is that the high quercetin concentrations used in many cell culture studies may not apply to the lower plasma concentrations achievable through oral quercetin supplementation. Nonetheless, epidemiologic studies indicate that individuals ingesting quercetin from fruits and vegetables experience a reduced risk for lung cancer and ischemic heart disease, with these benefits apparently related to quercetin's antioxidative and anti-inflammatory capacities. The high-dose quercetin ingestion in this study and a previous study in our laboratory failed to counter exercise-induced perturbations in inflammation, plasma cytokines, and oxidative stress. ${ }^{35}$ It can be argued that the degree of oxidative, inflammatory, and physiologic stress acutely induced by prolonged and intensive exertion overwhelms attempts to apply nutritional countermeasures and that quercetin ingestion is more effective within the context of countering the inflammation and oxidative stress related to chronic disease.

Race time was about $1 \mathrm{~h}(4 \%)$ shorter in the quercetin compared with the placebo group, but this did not achieve statistical significance. MacRae and Mefferd ${ }^{37}$ reported that 6 weeks of antioxidant supplement with quercetin $(600 \mathrm{mg} /$ day $)$ by 11 elite male cyclists decreased the time to complete a $30-\mathrm{km}$ time trial by $3.1 \%$. These authors speculated that the performance improvement could have been related to quercetin's effects on skeletal muscle redox state, reductions in muscle inflammation and protection of skeletal muscle protein, and facilitation of motor unit recruitment. Environmental conditions during the 2006 WSER were severe, and other confounding factors during this difficult and long trail race create a context that is less than ideal to test quercetin's potential effects on performance.

Plasma cytokine levels following the $160-\mathrm{km}$ race rose to levels similar to what we have previously reported. ${ }^{3-5}$ In a previous laboratory study during which 12 athletes cycled intensively for $2 \mathrm{~h}$, blood leukocyte mRNA expression for IL-10 increased 2.7-fold, IL-1Ra 2.2-fold, and IL-8 2.4-fold, with little change in IL- $6{ }^{8}$ Following the $160-\mathrm{km}$ WSER, changes in blood leukocyte mRNA expression were comparable to the laboratory study for IL-1Ra and IL-6, with a much higher and lower fold change recorded for IL-10 and IL-8, respectively. These data are difficult to interpret because of the lack of congruence between plasma cytokine levels and blood leukocyte cytokine mRNA expression. ${ }^{8}$ Nonetheless, the marked decrease in leukocyte IL-8 and increase in IL-10 mRNA expression are notable findings and suggest an attempt by the immune system to limit polymorphonuclear cell adherence, degranulation, respiratory burst activity, and inflammation when the athlete is already experiencing significant muscle cell damage and oxidative stress.

In conclusion, using randomized, double-blinded procedures, $1 \mathrm{~g} /$ day quercetin ingestion for 3 weeks prior to the $160-\mathrm{km}$ WSER did not counter changes in blood leukocyte cytokine mRNA or the large increases in inflammation, muscle soreness, and plasma cytokines experienced by the athletes. We suggest that quercetin's failure to exert effects in our human athletes anticipated from in vitro studies may have been due to several factors, including quercetin conjugation following ingestion, the large drop in plasma quercetin levels during the race event, the overwhelming level of oxidative stress and inflammation induced by running a competitive $160-\mathrm{km}$ trail race, or the inherent lack of association between oxidative stress and exercise-induced cytokine production within the context of extreme exertion. In a previous study, we showed that quercetin ingestion lowered the incidence of upper respiratory tract infection in athletes following a period of intensified exercise. ${ }^{35}$ Quercetin's pronounced antiviral capacities have been linked in vitro at least in part to quercetin methylated conjugates. These are common quercetin metabolites in humans, thus providing a physiologic rationale for our finding. ${ }^{38}$ Only a few in vitro studies have tested quercetin's impressive antioxidant and anti-inflammatory effects using physiologically relevant metabolites, and this research is needed to test the value of quercetin supplementation for endurance athletes beyond the disease reduction benefits shown by epidemiologic research.

\section{ACKNOWLEDGMENTS}

This work was partially supported by a grant from the Defense Advanced Research Projects Agency (DARPA) and the Army Research Office (ARO), award No. W911NF-06-0014. We acknowledge Quercegen Pharma (Newton, MA) for providing QU995 soft chews and placebo for this research project.

\section{REFERENCES}

1. Suzuki K, Totsuka M, Nakaji S, Yamada M, Kudoh S, Liu Q, Sugawara K, Yamaya K, Sato K. Endurance exercise causes interaction among stress hormones, cytokines, neutrophil dynamics, and muscle damage. J. Appl. Physiol. 1999;87:1360-1367.

2. Nieman DC, Henson DA, McAnulty SR, McAnulty LS, Morrow JD, Ahmed A, Heward CB. Vitamin E and immunity after the Kona Triathlon World Championship. Med. Sci. Sports Exerc. 2004;36: 1328-1335.

3. Nieman DC, Dumke CL, Henson DA, McAnulty SR, Gross SJ, Lind RH. Muscle damage is linked to cytokine changes following a 160-km race. Brain Behav. Immun. 2005;19:398-403.

4. Nieman DC, Oley K, Henson DA, Dumke CL, McAnulty SR, Davis JM, Murphy EA, Lind RH. Ibuprofen use, endotoxemia, inflammation, and plasma cytokines during ultramarathon competition. Brain Behav. Immun. 2006;20:578-584.

5. Nieman DC, Dumke CL, Henson DA, McAnulty SR, McAnulty LS, Lind RH, Morrow JD. Immune and oxidative changes during and following the Western States Endurance Run. Int. J. Sports Med. 2003;24:541-547.

6. Nieman DC, Davis JM, Henson DA, Walberg-Rankin J, Shute M, Dumke CL, Utter AC, Vinci DM, Carson J, Brown A, Lee WJ, McAnulty SR, McAnulty LS. Carbohydrate ingestion influences skeletal muscle cytokine mRNA and plasma cytokine levels after a 3-h run. J. Appl. Physiol. 2003;94:1917-1925.

7. Nieman DC, Davis JM, Henson DA, Gross SJ, Dumke CL, Utter AC, Vinci DM, Carson JA, Brown A, McAnulty SR, McAnulty LS, Triplett NT. Skeletal muscle cytokine mRNA and plasma cytokine changes after 2.5-h cycling: influence of carbohydrate. $\underline{\mathrm{Med}}$. Sci. Sports Exerc. 2005;37:1283-1290.

8. Nieman DC, Henson DA, Davis JM, Dumke CL, Utter AC, Murphy EA, Pearce S, Gojanovich G, McAnulty SR, McAnulty LS. 
Blood leukocyte mRNA expression for IL-10, IL-1ra, and IL-8, but not IL-6, increases after exercise. J. Interferon Cytokine Res. 2006;26:668-674.

9. Steensberg A, Keller C, Hillig T, Fr sig C, Wojtaszewski JFP, Pedersen BK, Pilegaard H, Sander M. Nitric oxide production is a proximal signaling event controlling exercise-induced mRNA expression in human skeletal muscle. FASEB J. 2007;21:2683-2694.

10. Erdman JW, Balentine D, Arab L, Beecher G, Dwyer JT, Folts J, Harnly J, Hollman P, Keen CL, Mazza G, Messina M, Scalbert A, Vita J, Williamson G, Burrowes J. Flavonoids and heart health: Proceedings of the ILSI North America Flavonoids Workshop, May 31-June 1, 2005, Washington, DC. J. Nutr. 2007;137:718S-737S.

11. Manach C, Scalbert A, Morand C, Rémésy C, Jiménez L. Polyphenols: food sources and bioavailability. Am. J. Clin. Nutr. 2004;79: 727-747.

12. Manach C, Williamson G, Morand C, Scalbert A, Rémésy C. Bioavailability and bioefficiency of polyphenols in humans. 1. Review of 97 bioavailability studies. Am. J. Clin. Nutr. 2005; 81(Suppl):230S-242S.

13. Walle T, Walle UK, Halushka PV. Carbon dioxide is the major metabolite of quercetin in humans. J. Nutr. 2001;131:2648-2652.

14. De Boer VCJ, Dihal AA, van der Woude H, Arts ICW, Wolffram S, Alink GM, Rietjens IMCM, Keijer J, Hollman PEH. Tissue distribution of quercetin in rats and pigs. J. Nutr. 2005;135:17181725 .

15. Okamoto T. Safety of quercetin for clinical application. Int. J. Mol. Med. 2005;16:275-278.

16. Theodoratou E, Kyle J, Cetnarskyj R, Farrington SM, Tenesa A, Barnetson R, Porteous M, Dunlop M, Campbell H. Dietary flavonoids and the risk of colorectal cancer. Cancer Epidemiol. Biomarkers Prev. 2007;16:684-693.

17. McCann SE, Ambrosone CB, Moysich KB, Brasure J, Marshall JR, Freudenheim JL, Wilkinson GS, Graham S. Intakes of selected nutrients, foods, and phytochemicals and prostate cancer risk in western New York. Nutr. Cancer 2005;53:33-41.

18. Neuhouser ML. Dietary flavonoids and cancer risk: evidence from human population studies. Nutr. Cancer 2004;50:1-7.

19. Knekt P, Kumpulainen J, JÑ̃rvinen R, Rissanen H, Helî̂vaara M, Reunanen A, Hakulinen T, Aromaa A. Flavonoid intake and risk of chronic diseases. Am. J. Clin. Nutr. 2002;76:560-568.

20. Nair MP, Mahajan S, Reynolds JL, Aalinkeel R, Nair H, Schwartz $\mathrm{SA}$, Kandaswami C. The flavonoid quercetin inhibits proinflammatory cytokine (tumor necrosis factor alpha) gene expression in normal peripheral blood mononuclear cells via modulation of the NF- $\kappa$ B system. Clin. Vaccine Immunol. 2006;13:319-328.

21. Comalada M, Ballester I, Bailón E, Sierra S, Xaus J, Gálvez J, de Medina FS, Zarzuelo A. Inhibition of pro-inflammatory markers in primary bone marrow-derived mouse macrophages by naturally occurring flavonoids: analysis of the structure-activity relationship. Biochem. Pharmacol. 2006;72:1010-1021.

22. Chen JC, Ho FM, Chao PDL, Chen CP, Jeng KCG, Hsu HB, Lee $\mathrm{ST}$, Wu WT, Lin WW. Inhibition of iNOS gene expression by quercetin is mediated by the inhibition of $\mathrm{I} \kappa \mathrm{B}$ kinase, nuclear factor-kappa B and Stat1, and depends on heme oxygenase-1 induction in mouse BV-2 microglia. Eur. J. Pharmacol. 2005;521:9-20.

23. Martínez-Flórez S, Gutiérrez-Fernández B, Sánchez-Campos S, González-Gallego J, Tunón MJ. Quercetin attenuates nuclear factor- $\kappa \mathrm{B}$ activation and nitric oxide production in interluekin- $1 \beta$-activated rat hepatocytes. J. Nutr. 2005;135:1359-1365.

24. Nam NH. Naturally occurring NFкB inhibitors. Mini Rev. Med. Chem. 2006;6:945-951.

25. Dias AS, Porawski M, Alonso M, Marroni N, Collado PS, González-Gallego J. Quercetin decreases oxidative stress, NF $\kappa$ B activation, and iNOS overexpression in liver of streptozotocin-induced diabetic rats. J. Nutr. 2005;135:2299-2304.
26. Ciz M, Pavelkova M, Gallova L, Kralova J, Kubala L, Lojek A. The influence of wine polyphenols on reactive oxygen and nitrogen species production by rat macrophages RAW 264.7. Physiol. Res. 2007 [Epub ahead of print].

27. Rahman I, Biswas SK, Kirkham PA. Regulation of inflammation and redox signaling by dietary polyphenols. Biochem. Pharmacol. 2006; 72:1439-1452.

28. García-Mediavilla V, Crespo I, Collado PS, Esteller A, SánchezCampos S, Tunón MJ, González-Gallego J. The anti-inflammatory flavones quercetin and kaempferol cause inhibition of inducible nitric oxide synthase, cyclooxygenase- 2 and reactive $\mathrm{C}$-protein, and downregulation of the nuclear factor kappaB pathway in Chang liver cells. Eur. J. Pharmacol. 2007;557:221-229.

29. Li X, Stark GR. NF $\kappa$ B-dependent signaling pathways. Exp. Hematol. 2002;30:285-296.

30. Ishii K, Furuta T, Kasuya Y. High-performance liquid chromatographic determination of quercetin in human plasma and urine utilizing solid-phase extraction and ultraviolet detection. J. Chromatogr. 2003;794:49-56.

31. Winer J, Jung CKS, Shackel I, Williams PM. Development and validation of real-time quantitative reverse transcriptase-polymerase chain reaction for monitoring gene expression in cardiac myocytes in vitro. Anal. Biochem. 1999;270: 41-49.

32. Livak KJ, Schmittgen TD. Analysis of relative gene expression data using real-time quantitative PCR and the $2^{-\Delta \Delta} C_{t}$ method. Methods 2001;25: 402-408.

33. Dill DB, Costill DL. Calculation of percentage changes in volumes of blood, plasma, and red cells in dehydration. J. Appl. Physiol. 1974;37:247-248.

34. Smith LL, Brunetz MH, Chenier TC, McCammon MR, Houmard JA, Franklin ME, Israel RG. The effects of static and ballistic stretching on delayed onset muscle soreness and creatine kinase. Res. Q. Exerc. Sports 1993;64:103-107.

35. Nieman DC, Henson DA, Gross SJ, Jenkins DP, Davis JM, Murphy EA, Carmichael MD, Dumke CL, Utter AC, McAnulty SR, McAnulty LS, Mayer EP. Quercetin reduces illness but not immune perturbations after intensive exercise. Med. Sci. Sports Exerc. 2007;39:1561-1569.

36. Mastaloudis A, Traver MG, Carstensen K, Widrick JJ. Antioxidants did not prevent muscle damage in response to an ultramarathon run. Med. Sci. Sports Exerc. 2006;38:72-80.

37. MacRae HSH, Mefferd DM. Dietary antioxidant supplementation combined with quercetin improves cycling time trial performance. Int. J. Sport Nutr. Exerc. Metab. 2006;16:405-419.

38. Dimova S, Mugabowindekwe R, Willems T, Brewster ME, Noppe M, Ludwig A, Jorissen M, Augustijns P. Safety-assessment of 3methoxyquercetin as an antirhinoviral compound for nasal application: effect on ciliary beat frequency. Int. J. Pharm. 2003;263: 95-103.

Address reprint requests or correspondence to:

Dr. David C. Nieman

Departments of Health, Leisure, and Exercise Science Fischer Hamilton/Nycom Biochemistry Laboratory Appalachian State University P.O. Box 32071 Boone, NC 28608

Tel: (828) 262-6318

Fax: (828) 262-3138 E-mail: niemandc@appstate.edu

Received 29 May 2007/Accepted 2 July 2007 



\section{This article has been cited by:}

1. Mónica Sousa, Vítor H. Teixeira, José Soares. 2013. Dietary strategies to recover from exercise-induced muscle damage. International Journal of Food Sciences and Nutrition 1-13. [CrossRef]

2. J. Mark Davis, Benjamin Gordon, E. Angela Murphy, Martin D. CarmichaelDietary Phytochemicals 277-290. [CrossRef]

3. David C. Nieman, Beibei Luo, Didier Dréau, Dru A. Henson, R. Andrew Shanely, Dustin Dew, Mary Pat Meaney. 2013. Immune and inflammation responses to a 3-day period of intensified running versus cycling. Brain, Behavior, and Immunity . [CrossRef]

4. Ilaria Peluso, Cristiana Miglio, Giuseppa Morabito, Francesca Ioannone, Mauro Serafini. 2013. Flavonoids and immune function in human: a systematic review. Critical Reviews in Food Science and Nutrition 130802085346007. [CrossRef]

5. Lisa S. McAnulty, Lindsey E. Miller, Peter A. Hosick, Alan C. Utter, John C. Quindry, Steven R. McAnulty. 2013. Effect of resveratrol and quercetin supplementation on redox status and inflammation after exercise. Applied Physiology, Nutrition, and Metabolism 38:7, 760-765. [CrossRef]

6. Ilaria Peluso, Anna Raguzzini, Mauro Serafini. 2013. Effect of flavonoids on circulating levels of TNF- $\alpha$ and IL-6 in humans: A systematic review and meta-analysis. Molecular Nutrition \& Food Research 57:5, 784-801. [CrossRef]

7. R. A. Shanely, D. C. Nieman, D. A. Henson, F. Jin, A. M. Knab, W. Sha. 2013. Inflammation and oxidative stress are lower in physically fit and active adults. Scandinavian Journal of Medicine \& Science in Sports 23:2, 215-223. [CrossRef]

8. F Ioannone, C Miglio, A Raguzzini, M Serafini, G MorabitoFlavonoids and immune function 379-415. [CrossRef]

9. Alyson Mitchell, Jihyun Lee, Valeria AcquaroneLiterature Review on the Ergogenic Effects of Quercetin 165-180. [CrossRef]

10. E. Angela Murphy, J. Mark Davis, Jamie L. McClellan, Martin D. Carmichael, Nico Van Rooijen, J. David Gangemi. 2011. Susceptibility to Infection and Inflammatory Response Following Influenza Virus (H1N1, A/PR/8/34) Challenge: Role of Macrophages. Journal of Interferon \& Cytokine Research 31:6, 501-508. [Abstract] [Full Text HTML] [Full Text PDF] [Full Text PDF with Links]

11. Amy M. Knab, R. Andrew Shanely, Fuxia Jin, Melanie D. Austin, Wei Sha, David C. Nieman. 2011. Quercetin with vitamin C and niacin does not affect body mass or composition. Applied Physiology, Nutrition, and Metabolism 36:3, 331-338. [CrossRef]

12. HYO JEONG KIM, CÉCILE JAMART, LOUISE DELDICQUE, GANG-LI AN, YOON HEE LEE, CHANG KEUN KIM, JEAN-MARC RAYMACKERS, MARC FRANCAUX. 2011. Endoplasmic Reticulum Stress Markers and Ubiquitin-Proteasome Pathway Activity in Response to a 200-km Run. Medicine \& Science in Sports \& Exercise 43:1, 18-25. [CrossRef]

13. Javier González-Gallego, M. Victoria García-Mediavilla, Sonia Sánchez-Campos, María J. Tuñón. 2010. Fruit polyphenols, immunity and inflammation. British Journal of Nutrition 104:S3, S15-S27. [CrossRef]

14. Serena A. Heinz, Dru A. Henson, David C. Nieman, Melanie D. Austin, Fuxia Jin. 2010. A 12-week supplementation with quercetin does not affect natural killer cell activity, granulocyte oxidative burst activity or granulocyte phagocytosis in female human subjects. British Journal of Nutrition 104:06, 849-857. [CrossRef]

15. Mauro Serafini, Ilaria Peluso, Anna Raguzzini. 2010. Flavonoids as anti-inflammatory agents. Proceedings of the Nutrition Society 69:03, 273-278. [CrossRef]

16. F Jin, D C Nieman, R A Shanely, A M Knab, M D Austin, W Sha. 2010. The variable plasma quercetin response to 12-week quercetin supplementation in humans. European Journal of Clinical Nutrition 64:7, 692-697. [CrossRef]

17. Megan L.R. Ross, Shona L. Halson, Katsuhiko Suzuki, Andrew Garnham, John A. Hawley, David Cameron-Smith, Jonathan M. Peake. 2010. Cytokine Responses to Carbohydrate Ingestion During Recovery from Exercise-Induced Muscle Injury. Journal of Interferon \& Cytokine Research 30:5, 329-337. [Abstract] [Full Text HTML] [Full Text PDF] [Full Text PDF with Links]

18. Matthew S. Ganio, Lawrence E. Armstrong, Evan C. Johnson, Jennifer F. Klau, Kevin D. Ballard, Bozena Michniak-Kohn, Diksha Kaushik, Carl M. Maresh. 2010. Effect of quercetin supplementation on maximal oxygen uptake in men and women. Journal of Sports Sciences 28:2, 201-208. [CrossRef]

19. David C. Nieman. 2009. Immune Function Responses to Ultramarathon Race Competition. Medicina Sportiva 13:4, 189-196. [CrossRef]

20. DAVID C. NIEMAN, DRU A. HENSON, KENDRA R. MAXWELL, ASHLEY S. WILLIAMS, STEVEN R. MCANULTY, FUXIA JIN, R. ANDREW SHANELY, THOMAS C. LINES. 2009. Effects of Quercetin and EGCG on Mitochondrial Biogenesis and Immunity. Medicine \& Science in Sports \& Exercise 41:7, 1467-1475. [CrossRef]

21. J. Mark Davis, E. Angela Murphy, Martin D. Carmichael. 2009. Effects of the Dietary Flavonoid Quercetin Upon Performance and Health. Current Sports Medicine Reports 8:4, 206-213. [CrossRef]

22. Stephan C Bischoff. 2008. Quercetin: potentials in the prevention and therapy of disease. Current Opinion in Clinical Nutrition and Metabolic Care 11:6, 733-740. [CrossRef] 
23. David C Nieman. 2008. Immunonutrition support for athletes. Nutrition Reviews 66:6, 310-320. [CrossRef]

24. David C. Nieman. 2008. RESPONSE. Medicine \& Science in Sports \& Exercise 40:4, 776. [CrossRef] 